\title{
Peranan Komisaris dan Direksi Bank Syariah dalam Pengelolaan Dana Zakat dan ISR (Islamic Social Responsibility) di Indonesia
}

\author{
Melia Frastuti1 ${ }^{1}$ Dimas Pratama Putra ${ }^{2}$, Erfan Effendi 3 \\ 1 Jurusan Akuntansi, Universitas Tridinanti Palembang \\ Email:melia-frastuti@univ-tridinanti.ac.id \\ 2 Jurusan Akuntansi, Universitas Tridinanti Palembang \\ Email: dimaspratama190491@gmail.com \\ 3 Jurusan Manajemen, Universitas Islam Riau \\ Email: effendierfan@eco.uir.ac.id.
}

\begin{abstract}
Almsgiving is one of the pillars supporting the upholding of Islam as the obligation for the adherents to improve horizontal relations between fellow humans and strengthen vertical relations with Allah SWT. The implementation of Islamic Social Responsibility (ISR) of the Islamic Bank gives a positive assessment in sharia agreement, justice and equality, responsibility for work, welfare, guarantee of nature preservation and benevolent assistance that is not profit-oriented.

Proper almsgiving management and ISR implementation make Islamic banks trusted by the public in terms of service quality, satisfaction and loyalty of Muzzaki. It reduces bad images, and provides relevant impacts on social welfare and the progress of the era. The data analysis used to test the hypotheses is Multiple Linear Regression analysis. The data is collected by distributing questionnaires to Commissioners and Directors at 14 (fourteen) Islamic Commercial Banks spread throughout Indonesia. The result of this study shows partially prove the role of Islamic bank commissioners in the amsgiving management only, while the importance of the role of directors in Islamic banks in almsgiving management and the implementation of ISR partially.
\end{abstract}

Keywords: Islamic Bank, Commissioners, Directors, Almsgiving and ISR

\begin{abstract}
Abstrak
Zakat menjadi salah satu rukun penyangga tegaknya Islam serta kewajiban bagi pemeluknya memperbaiki hubungan horizontal antara sesama manusia dan memperkuat hubungan vertikal manusia dengan Allah SWT. Pelaksanaan Islamic Social Responsibility (ISR) Bank Syariah memberikan dampak positif dalam kepatuhan syariah, keadilan dan kesetaraan, bertanggung jawab dalam bekerja, jaminan kesejahteraan, jaminan kelestarian alam serta bantuan kebajikan yang tidak hanya berorientasi pada keuntungan semata-mata.

Pengelolaan Zakat dan Pelaksanaan ISR yang tepat membuat bank syariah dipercaya masyarakat dalam service quality, kepuasan dan loyalitas Muzzaki, mengurangi image buruk, serta memberikan dampak yang relevan dalam kesejahteraan sosial dan kemajuan zaman. Analisis data yang digunakan untuk menguji hipotesis menggunakan analisis Multiple Linear Regressions. Pengumpulan data dengan pendistribusian kuesioner kepada Komisaris dan Direksi pada 14 Bank Umum Syariah yang tersebar di Indonesia. Hasil penelitian ini membuktikan secara parsial adanya peranan komisaris bank syariah dalam pengelolaan zakat saja, sedangkan besarnya peranan direksi di bank syariah dalam pengelolaan zakat dan pelaksanaan ISR secara parsial.
\end{abstract}

Kata kunci: Bank Syariah, Komisaris, Direksi, Zakat dan ISR 
Pendahuluan

Salah satu ajaran dalam Islam yang bertujuan mengatasi kesenjangan dan gejolak sosial adalah zakat. Zakat menjadi kewajiban bagi pemeluknya membawa misi perbaikan hubungan horizontal antara sesama manusia yang pada akhirnya mampu mengurangi gejolak akibat problematika kesenjangan dalam hidup mereka. (Mujahidin, 2017: 67).

Badan Amil Zakat Nasional mendata di Tahun 2017 ada 150,2 orang Muzakki yang aktif kemudian dana zakat tersebut dihimpun sebanyak 158,7 Milyar Rupiah selanjutnya disalurkan disalurkan sebanyak 101,9 Milyar Rupiah kepada 305,4 orang Mustahik (http://baznas.go.id). berikut:

Grand Strategy Pengembangan Pasar Perbankan Syariah dapat dilihat sebagai

1. Menerapkan visi pengembangan perbankan syariah pada fase I tahun 2008 membangun pemahaman perbankan syariah sebagai Beyond Banking, dengan pencapaian target asset sebesar Rp.50 triliun dan pertumbuhan industri sebesar $40 \%$, fase II tahun 2009 menjadikan perbankan syariah Indonesia sebagai perbankan syariah paling atraktif di ASEAN, dengan pencapaian target asset sebesar Rp.87 triliun dan pertumbuhan industri sebesar 75\%. Fase III tahun 2010 menjadikan perbankan syariah Indonesia sebagai perbankan syariah terkemuka di ASEAN, dengan pencapaian target asset sebesar Rp.124 triliun dan pertumbuhan industri sebesar $81 \%$.

2. Program pencitraan baru perbankan syariah yang meliputi aspek positioning, differentiation, dan branding.

3. Program pemetaan baru secara lebih akurat terhadap potensi pasar perbankan syariah.

4. Program pengembangan produk yang diarahkan kepada variasi produk serta didukung oleh keunikan value yang ditawarkan.

5. Program peningkatan kualitas layanan didukung oleh SDM yang kompeten dan penyediaan teknologi informasi yang mampu memenuhi kebutuhan dan kepuasan nasabah serta mampu mengkomunikasikan produk/ jasa bank syariah secara benar dan jelas, serta tetap memenuhi prinsip syariah.

6. Program sosialisasi dan edukasi masyarakat secara lebih luas \& efisien melalui berbagai sarana komunikasi. (http://bi.go.id)

Efek zakat terhadap distribusi pendapatan tidak serta merta akan menjadikan pendapatan masyarakat menjadi adil dan merata. Hal ini dipengaruhi oleh beberapa hal, seperti distribusi faktor produksi di suatu negara, gaya hidup masyarakat, proporsi masyarakat penerima zakat, dan sebagainya. Sebagai contoh, ketika masyarakat miskin sangat konsumtif serta rantai produksi barang dikuasai sekelompok orang, maka pelaksanaan zakat tidak akan memberikan dampak signifikan bagi redistribusi pendapatan. Efek penumpang gelap artinya adanya sekelompok yang mau menikmati layanan dengan tanpa memberikan kontribusi. Hal ini bisa terjadi jika zakat didistribusikan untuk penyediaan barang publik, seperti layanan ibadah atau pendidikan, maka insentif untuk melakukan perawatan atau kontribusi sosial menjadi rendah. Kita bisa melihat sarana pendidikan umum yang tidak layak, sebagai akibat adanya free rider effect. Maka, manajemen zakat harus berupaya untuk menekan efek ini. (DEKS BI-P3EI-FE UII: 27-28)

Pengembangan sektor komersial dan sosial itu penting untuk mendorong agar posisi sistem keuangan syariah sejajar dengan sistem konvensional. Penerapan dokumen Zakat Core Principles perlu ditingkatkan agar standar pengelolaan zakat semakin membaik. Bank Indonesia akan terus bekerja sama dengan MUI, Badan Wakaf Indonesia 
serta Baznas untuk pengembangan pasar keuangan syariah. (https://.tirto.id, 24/01/2018)

Cetak Biru Pengembangan Perbankan Syariah di Indonesia" memuat visi, misi dan sasaran pengembangan perbankan syariah serta sekumpulan inisiatif strategis dengan prioritas yang jelas untuk menjawab tantangan utama dan mencapai sasaran dalam kurun waktu 10 tahun ke depan, yaitu pencapaian pangsa pasar perbankan syariah yang signifikan melalui pendalaman peran perbankan syariah dalam aktivitas keuangan nasional, regional dan internasional, dalam kondisi mulai terbentuknya integrasi dgn sektor keuangan syariah lainnya.(https://bi.go.id)

Menghindari adanya efek kemubaziran dari pelaksanaan zakat, atau bahkan efek negatifnya, serta meningkatkan efek positif zakat bagi kesejahteraan umat, maka zakat harus dikelola dengan baik dan terencana. Pengelolaan zakat tidak bisa semata diserahkan kepada amil swasta yang tidak mampu bekerja secara profesional. Intervensi pihak ketiga, misalnya pemerintah, perlu dilakukan untuk

meningkatkan efektivitas dan efisiensi pengelolaan zakat. Tata kelola atau governance secara singkat dapat diartikan sebagai suatu sistem dan proses yang bisa memastikan arah secara keseluruhan, efektivitas, pengawasan dan akuntabilitas organisasi. Yang termasuk dalam struktur tata kelola Bank adalah Komisaris, Direksi, Komite, Dewan Pengawas Syariah, dan satuan kerja pada Bank. (No.10/SEOJK.03/2014). Setidaknya, ada lima prinsip tata kelola yang baik, yaitu kepatuhan terhadap hukum dan peraturan, organisasi dikelola dengan baik dan efisien, masalah-masalah diidentifikasi di awal dan ditangani dengan tepat, pelestarian reputasi dan integritas sektor, dan zakat ini dikelola secara professional dan unik serta memberikan nilai tambah yang lebih maju.(DEKS BIP3EI-FEUII, 2016:52).

Badan Amil Zakat Nasional mendata di tahun 2017 ada 150,2 orang Muzakki yang aktif kemudian dana zakat tersebut dihimpun sebanyak 158,7 Milyar Rupiah selanjutnya disalurkan disalurkan sebanyak 101,9 Milyar Rupiah kepada 305,4 orang Mustahik (https://baznas.go.id). Hal ini membuktikan besarnya kesadaran masyarakat untuk menunaikan zakat tersebut yang pada akhirnya bermanfaat bagi orang yang membutuhkannya sehingga ketimpangan sosial bisa dikurangi.

Zakat berperan penting dalam penanggulangan kemiskinan melalui jalur penciptaan lapangan pekerjaan. Kerangka konseptual social- ekonomi Islam mendorong penciptaan lapangan kerja melalui dua jalur: yaitu penciptaan pekerjaan dengan upah tetap (fixed-wage job) dan penciptaan peluang wirausahaan (entrepreneurial opportunities). Dan salah satu kerangka institusional terpenting dalam perekonomian Islam untuk penciptaan lapangan kerja yaitu zakat. (Mujahidin, 2017:26)

Kepatuhan syariah lembaga pengelola zakat harus mantap dengan manajemen keuangan, administrasi. Tapi juga tepat dengan ketentuan-ketentuan syariah, dan aturan-aturan agama, apalagi zakat diyakini mampu mengurangi kemiskinan. Programprogram zakat produktif penting dilakukan oleh pengelola zakat BAZNAS maupun LAS di Indonesia. Pengelolaan zakat harus dipastikan sesuai dengan ketentuan syariah, dalam pengumpulan pendistribusiannya dan pengelolaan keuangan. Semua amil zakat yang berkiprah di Baznas dan Lembaga amil zakat memiliki literasi yang tinggi dan semakin komprehensif dalam aspek syariah. Bahkan selain amil zakat, masyarakat juga harus memiliki kepedulian terhadap pengelolaan zakat yang taat azas dalam berinovasi, berkreasi dalam mengembangkan produk- produk pengelolaan zakat yang panduannya jelas, fatwa-fatwa MUI sudah ada bahkan standar kepatuhan syariah yang sesuai dengan prinsi-prinsip internasional dalam pengelolaan keuangan syariah juga sudah ada. (https://republika.co.id). 
Diharapkan peranan Komisaris dan Direksi Bank syariah dalam menciptaan ideide kreatif mengenai pengelolaan dana zakat bisa memberikan dampak positif tersebut. Jumlah Bank syariah sebenarnya bisa menjadi pilar perkembangan pengelolaan dana zakat.

Tahun 2019 OJK mencatat ada 1885 unit jumlah kantor Bank Umum Syariah dari 14 jenis Bank Umum Syariah, 195 unit jumlah Kantor Unit Usaha Syariah dan 304 unit Bank Pembiayaan Syariah Rakyat Syariah.

Fungsi sosial perbankan syariah sebagaimana diatur dalam Pasal 4 UndangUndang Nomor 21 Tahun 2008 ayat 2-4 Tentang Perbankan Syariah adalah: (2) Bank syariah dan Unit Usaha Syariah dapat menjalankan fungsi sosial dalam bentuk lembaga bait al maal, yaitu menerima dana yang berasal dari zakat, infaq, sedekah, hibah atau dana sosial lainnya dan menyalurkannya kepada pengelola wakaf (nazir) sesuai dengan kehendak pemberi wakaf (wakif). (3)Bank syariah dan Unit Usaha Syariah dapat menghimpun dana sosial yang berasal dari uang dan menyalurkannya kepada pengelolaan wakaf (nazir) sesuai dengan kehendak pemberi wakaf (wakif). (4) Pelaksanaan fungsi sosial sesuai dengan kehendak pemberi wakaf (wakif).

Syarat harta kekayaan yang wajib dizakatkan atau objek menurut Hery (2018: 122-123) adalah: halal, miliki penuh, berkembang, cukup nisab, cukup haul, bebas dari utang, lebih dari kebutuhan pokok.

Zakat sebagai salah satu sumber daya ekonomi dan instrumen penanggulangan masalah perekonomian berbasis prinsip syariah, memerlukan dukungan pemerintah dan pelembagaan pengelolaan yang baik. Selanjutnya, untuk mencapai tujuan zakat secara berhasil guna dan berdaya guna, maka suatu organisasi perlu menerapkan asas-asas tertentu dalam operasional kelembagaan.

Bebarapa prinsip yang menjadi azas kelembagaan organisasi pengelola zakat, adalah asas kemashlahatan umum, asas pembagian tugas, asas fungsionalisasi, asas koordinasi adalah asas kemashlahatan umum, asas koordinasi dan asas kesinambungan. Asas kemashlahatan umum zakat yang dikelola melalui organisasi dan manajemen secara baik diharapkan membawa dampak bagi lahirnya kesadaran bagi para muzzaki, munfik, dan mushaddiq dalam menunaikan kewajiban dan anjuran agama. (Dakhoir, 2015: 56-57)

Secara keseluruhan, zakat akan berkontribusi positif pada pertumbuhan ekonomi baik melalui jalur permintaan agregat (agregat demand) maupun jalur penawaran agregat (aggregate supply). Dampak positif zakat pada konsumsi dan investasi secara jelas akan menaikkan permintaan agregat dalam perekonomian. Kombinasi dampak zakat terhadap konsumsi dan investasi akan meningkatkan permintaan (multiplier effect) dalam perekonomian, hal ini akan membawa pada peningkatan Pendapatan Nasional. (Wibisono, 2016: 50 dan 67)

\section{Tinjauan Pustaka}

\section{Sumber Hukum Zakat}

Kata zakat disebut 30 kali dalam Al-Qur'an (27 kali dalam satu ayat bersama sholat, 1 kali tidak dalam satu ayat tapi masih dalam satu konteks dengan sholat. 8 kata zakat terdapat dalam surat yang diturunkan di Mekah, dan 22 kata zakat yang diturunkan di Madinah. (Nurhayati, 2016:287)

Zakat bersama- sama dengan instrumen filantropi Islam lainnya, yang merupakan kewajiban moral Muslim untuk melakukan kebaikan material atas nama Tuhan, 
pelaksanaanya lebih banyak ditentukan oleh kesadaran dan keyakinan individu dibandingkan dengan enforcement kekuasaan Negara. (Wibisono, 2016:133)

Menurut Mujahidin (2017:69) kewajiban zakat yang terdapat dalam Al-Qur'an dan hadis di atas bersifat mutlak dan ijbariy. Artinya, kewajiban tersebut tidak sepenuhnya diserahkan kepada pemilik harta, tapi pemerintah harus ikut turun tangan memungut langsung dari mereka walau dengan paksaan.

\section{Konsep Pengelolaan Zakat}

Konsep pengelolaan zakat menurut Parasuraman (1985) dalam Huda (2019: 175) yaitu Model Servqual, kualitas jasa didefinisikan sebagai penilaian atau sikap global berkenaan dengan superperioritas suatu jasa, Kepuasan pelanggan (Customer Satisfaction) dan loyalitas pelanggan (Customer Loyalty). Hasan (2015:92) meyimpulkan bila ekonomi umat Islam sudah baik tentu penyaluran zakat tidak susah dan rumit, sebab sudah jelas tempat penyalurannya namun ketelitian dan kecermatan para amil zakat sangat diperlukan.

Menurut PSAK 109 tentang akuntansi zakat dan infak/ sedekah telah disahkan oleh Dewan Standar Akuntansi Syariah pada 6 April 2010. Zakat yang diterima dari Muzzaki diakui sebagai penambah dana zakat sebesar (ayat 11):

a. Jumlah yang diterima, jika dalam bentuk kas

b. Nilai wajar dalam bentuk nonkas.

\section{Ekonomi Zakat}

Menurut Wibisono (2016:7) dari aspek mikro-ekonomi, zakat memiliki berbagai implikasi ekonomi yag penting antara lain terhadap konsumsi agregat, tabungan nasional, investasi dan produksi agregat. Dalam perekonomian Islam dimana zakat diterapkan, maka masyarakat akan terbagi dalam dua kelompok pendapatan yaitu pembayar zakat dan penerima zakat. Kelompok masyarakat wajib zakat (muzzaki) akan mentransfer sejumlah proporsi pendapatan mereka ke kelompok masyarakat penerima zakat (mustahik). Hal ini secara jelas akan membuat pendapatan yang siap dibelanjakan (disposable income) dari mustahik akan meningkat. Peningkatan pendapatan disposable akan meningkatkan konsumsi dan sekaligus mengizinkan mustahik untuk memulai membentuk tabungan. Dalam jangka panjang, transfer zakat akan membuat ekspekstasi pendapatan dan tingkat kekayaan mustahik meningkat yang pada gilirannya membuat konsumsi mereka menjadi lebih tinggi lagi.

Dalam perspektif Islam, tabungan bukanlah aktivitas residual melainkan sebuah tindakan rasional yang memiliki tujuan tertentu yang positif, bukan untuk ditimbun atau digunakan untuk berspekulasi. Tabungan untuk persiapan di masa depan adalah diperbolehkan bahkan dianjurkan sesuai dengan :

QS Al-Hasyr ayat 18:

Wahai orang-orang yang beriman. Bertaqwalah kepada Allah dan hendaklah setiap orang memperhatikan apa yang telah diperbuatnya untuk hari esok (akhirat), dan bertaqwalah kepada Allah. Sungguh, Allah maha Mengetahui terhadap apa yang kamu kerjakan.

dan QS Al-Furqan ayat 67:

Dan (termasuk hamba-hamba Tuhan Yang Maha Pengasih) orang-orang yang apabila menginfakkan (harta), mereka tidak berlebihan, dan tidak (pula) kikir, diantara keduanya secara wajar.

Monzer Kahf (1980) dalam Wibisono (2016:11) secara makro, penerapan zakat akan berdampak positif terhadap tingkat tabungan nasional. Karena zakat juga 
dikenakan terhadap kekayaan (wealth) yang terakumulasi, tidak hanya pada penapatan (income) saja, maka pembayaran zakat akan mendorong muzzaki untuk meningkatkan rasio tabungan untuk mencegah tingkat kekayaannya menurun.

Senada dengan M Fahim Khan (1995) dalam Wibisono (2016:12) Motivasi untuk menabung dalam perekonomian Islam adalah expcted rate of return on savings, bukan suku tabungan (interest rate). Dalam Islam, zakat diterapkan pada tabungan sehingga nilai tabungan akan turun setiap tahunnya sebesar tarif zakat. Untuk mempertahankan tingkat kekayaan konstan atau mengembangkannya, maka tabungan harus diinvestasikan pada kegiatan produktif di sektor riil. Dengan demikian rate of return on saving sepenuhnya ditentukan rasio bagi hasil dan tingkat pengembalian (return) proyek karena tarif zakat adalah konstan.

Selain mengharapkan return, motivasi menabung lainnya yaitu untuk berjagajaga (preautionary) menghadapi ketidakpastian di masa depan. Dengan kata lain, menabung digunakan sebagai stok penyangga (buffer stock). Transfer zakat ke kelompok miskin, akan meningkatkan kemampuan kelompok ini untuk menabung. Di sisi lain, kelompok kaya akan mempertahankan tingkat tabungannya dari menurunkan akibat penalti zakat. Dengan demikian, penerapan zakat akan menurunkan pengeluaran yang berlebihan dari kelompok kaya dengan dampak positif terhadap tabungan kelompok miskin (Wibisono, 2016:12)

Menurut Adiwarman (2007) dalam Wibisono (2016:14) Zakat adalah instrumen yang memiliki distorsi pasar yang minimal. Pada kasus zakat perniagaan, hal ini terlihat pada kenyataan bahwa objek zakat adalah keuntungan perdagangan. dengan demikian, penerapan zakat tidak mempengaruhi struktur biaya dan tingkat keuntungan, harga jual dan kuantitas produksi. Upaya perusahaan memaksimalkan keuntungan, harga jual dan kuantitas produksi. Upaya perusahaan memaksimalkan keuntungan akan berjalan beriringan dengan upaya mamaksimalkan zakat.

Menurut Wibisono (2016:21-22) belanja dana zakat akan meningkatkan konsumsi kelompok miskin, yang kemudian akan memicu kenaikkan produksi barang dan jasa terkait belanja konsumsi kelompok miskin ini. Kenaikkan produksi dipastikan akan menggerakkan roda perekonomian secara luas berupa permintaan terhadap input faktor produksi seperti tenaga kerja, modal fisik, energi, dan bahan baku, hingga permintaan terhadap input antara (intermediary input), terutama produk dan jasa kebutuhan dasar yang umumnya dihasilkan oleh produsen domestik. Lebih jauh lagi, zakat juga menstimulus produksi dengan mengakomodasi kesulitan usaha, mendorong skala ekonomi dan memberi kepastian usaha. Produksi dengan tingkat kesulitan dan biaya yang lebih tinggi, memiliki tarif zakat yang lebih rendah, seperti tarif zakat pertanian dan zakat pertambangan. Adapun tarif zakat peternakan, tarif regresif zakat secara jelas mendorong produsen untuk beroperasi pada skala ekonomi yang besar untuk mencapai efisiensi produksi. tarif zakat yang tetap dan tidak pernah berubah, karena telah ditetapkan secara pasti di dalam syariah, akan memberikan kepastian usaha bagi pelaku ekonomi dan menciptakan iklim investasi yang baik. Secara singkat dapat dikatakan bahwa, sebagai instrumen fiskal zakat sangat ramah pasar (marketfriendly).

\section{Kajian Awal CSR}

Menurut Eberstads 1973 (Yusuf, 2017:27) Konsep CSR memberikan perhatian lebih oleh perusahaan sebagai tanggung jawabnya terhadap sistem sosial, sedangkan Yusuf (2017:32) menjelaskan bahwa pelaaksnaaan CSR mencakup dimensi lingkungan, 
sosial, ekonomi, pemegang kepentingan, etika, kebajikan dan tanggung jawab terhadap undang-undang.

Kaitan pelaksanaan program CSR dan public relations harus mempunyai programprogram yang dijalankan tepat sasaran yaitu: penelitian (research), perencanaan (planning), penggiatan (action) dan evaluasi (evaluation). (Putra:2019:75)

\section{Pengukuran Islamic Social Responsibility (ISR)}

Tabel 1. Aspek kinerja ISR, KBC dan FOZ (Wibisono, 2016:67)

\begin{tabular}{|c|c|c|}
\hline No & Aspek Kinerja & Indikator Kinerja \\
\hline 1 & Fund Raising & $\begin{array}{l}\text { Delta share dana dihimpun, New market gainer dana dihimpun, delta } \\
\text { share donator dan new market gainer donator }\end{array}$ \\
\hline 2 & Fund Distribution & $\begin{array}{l}\text { Rasio dana disalurkan/ dana dihimpun, delta share penerima manfaat, } \\
\text { new market gainer penerima manfaat }\end{array}$ \\
\hline 3 & $\begin{array}{l}\text { Management } \\
\text { System } \\
\text { Development }\end{array}$ & $\begin{array}{l}\text { Rasio dana dihimpun/SDM, Rasio dana disalurkan/SDM, Rasio } \\
\text { donator/SDM, Rasio penerima manfaat/SDM, Rasio trainingl SDM, } \\
\text { Penyususnan jangka panjang, Penyusunan rencana tahunan, } \\
\text { penyusunan laporan keuangan internal dan audited, publikasi laporan } \\
\text { keuangan di media internal dan eksternal }\end{array}$ \\
\hline
\end{tabular}

Sumber: Wibisono, 2016:67

\section{KERANGKA BERFIKIR}

Berikut kerangka berfikir dalam penelitian ini:

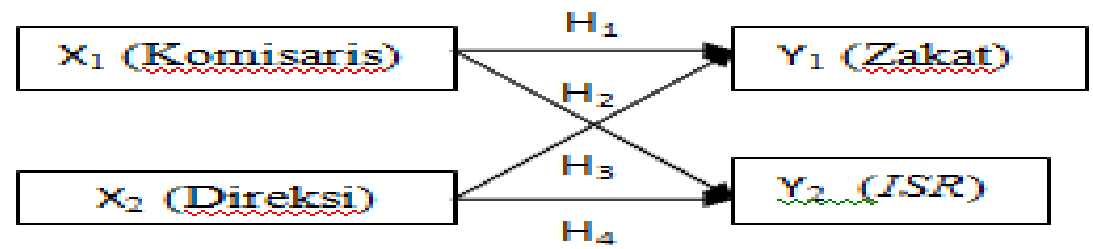

\section{Metode Penelitian}

\section{Gambar 1}

Dalam penelitian ini yang menjadi populasi yaitu Bank Umum Syariah (BUS) dan Unit Usaha Syariah (UUS) dan Bank Pembiayaan Rakyat Syariah (BPRS) di Indonesia, yaitu:

Tabel 2. Jenis Bank Syariah di Indonesia

\begin{tabular}{clc}
\hline No & \multicolumn{1}{c}{ Jenis Bank Syariah } & Jumlah (unit) \\
1 & Bank Umum Syariah (BUS) & 14 \\
2 & Unit Usaha Syariah (UUS) & 34 \\
3 & Bank Pembiayaan Rakyat Syariah (BPRS) & 33 \\
\multicolumn{2}{c}{ Total } & 81 \\
\hline \multicolumn{2}{c}{ Sumber: Statistik Perbankan Syariah- Januari 2019. http://ojk.go.id }
\end{tabular}

Jenis Bank Syariah di Indonesia dibedakan atas Bank Umum Syariah (BUS) berjumlah 14 unit, Unit Usaha Syariah (UUS) berjumlah 34 unit, dan berdasarkan lokasi Bank Pembiayaan Rakyat Syariah (BPRS) berjumlah 33 unit tersebar di seluruh Indonesia.

Jenis sampel yang digunakan adalah sampel sampling berlapis (sampling stratified). Menurut Hasan (2008) sampling berlapis adalah bentuk sampling random yang populasinya atau elemen populasinya dibagi dalam kelompok-kelompok yang disebut strata. 
Sampling stratified dilakukan apabila:

1. Elemen- elemen populasi heterogen.

2. Ada kriteria yang akan dipegunakan sebagai dasar untuk menstratifikasi populasi ke dalam stratum-stratum, misalnya variabel yang akan diteliti.

3. Adanya data pendahuluan dari populasi mengenai kriteria yang akan digunakan untuk stratifikasi.

4. Dapat diketahui dengan tepat jumlah satuan-satuan individu dari setiap stratum dalam populasi.

Proses pengerjaannya sebagai berikut: Hasan (2008)

1. Membagi populasi menjadi beberapa stratum.

2. Mengambil sebuah sampel random dari tiap stratum. Banyaknya unsur yang dipilih dari setiap stratum boleh sebanding atau tidak sebanding dengan jumlah stratum dalam populasinya. Jika pengambilan banyaknya unsur tiap stratum sebanding dengan ukuran-ukuran tiap stratum dan pengambilannya dilakukan secara random, dinamakan proportional random sampling.

3. Menggabungkan hasil dari pengambilan sampel tiap stratum, menjadi satu sampel yang diperlukan.

Kriteria yang digunakan dalam penelitian ini yaitu:

1. Bank Umum Syariah (BUS)

2. Memiliki Komisaris, Direktur dan Manajemen terpisah dari Bank Konvensionalnnya.

Berikut hasil sampling yang dilakukan:

Tabel 3. Sampling Penelitian

\begin{tabular}{clcc} 
No & \multicolumn{1}{c}{ Jenis Bank Syariah } & Jumlah (unit) & Sampling \\
1 & Bank Umum Syariah (BUS) & 14 & V \\
2 & Unit Usaha Syariah (UUS) & 34 & X \\
3 & Bank Pembiayaan Rakyat Syariah (BPRS) & 33 & X
\end{tabular}

Berdasarkan hasil kriteria sampling penelitian yang dilakukan maka Bank Umum Syariah (BUS) sebagai sampel penelitian. Berikut Nama Bank Umum Syariah di Indonesia yang dijadikan sampel:

\begin{tabular}{cl}
$\begin{array}{c}\text { Tabel } 4 . \text { Nama Bank Umum Syariah di Indonesia } \\
\text { No }\end{array}$ & \multicolumn{1}{c}{ Nama Bank Umum Syariah } \\
1 & PT Bank Aceh Syariah \\
2 & PT BPD Nusa Tenggara Barat Syariah \\
3 & PT Bank Mualamat Indonesia \\
4 & PT Bank Victoria Syariah \\
5 & PT BRI Syariah \\
6 & PT Bank Jabar Banten Syariah \\
7 & PT BNI Syariah \\
8 & PT Bank Mandiri Syariah \\
9 & PT Bank Mega Syariah \\
10 & PT Bank Panin Dubai Syariah \\
11 & PT Bank Syariah Bukopin \\
12 & PT Bank BCA Syariah \\
13 & PT Bank Tabungan Pensiun Nasional Syariah \\
14 & PT May Bank Syariah Indonesia \\
Sumber: Data Olahan Sekunder, Tahun 2019
\end{tabular}

Sampel penelitian berjumlah 14 (empat belas) Bank Umum Syariah yang Kantor Pusatnya di Jakarta ada 11 (sebelas) Bank Umum Syariah dan 3 (tiga) Bank Umum Syariah berkedudukan di Provinsi asal tempat berdiri yaitu : 
ISSN 2657-1080

ISSN 1858-3687

Akuntansi dan Manajemen Vol.14, No.2, 2019

1. PT Bank Aceh Syariah

2. PT Bank Nusa Tenggara Barat Syariah

3. PT Bank Jabar Banten Syariah

Total sampel yang digunakan ada 14 Bank Umum Syariah masing-masing 2 (dua) orang responden, yaitu: Komisaris atau wakil,(2 orang) dan Direksi atau wakil (2 orang). Sehingga jumlah sampel yang digunakan 1 (satu) Bank Umum Syariah berjumlah 4 responden dalam 14 Bank Umum Syariah sehingga total responden sebanyak 56 orang responden.

Indikator kinerja pengelolaan zakat sebagai berikut:

Tabel 5. Indikator Kinerja Pengelolaan Zakat

\begin{tabular}{|c|c|c|}
\hline No & Konstruksi & Pelaksanaan \\
\hline 1 & $\begin{array}{l}\text { Service } \\
\text { Quality }\end{array}$ & $\begin{array}{l}\text { Kemampuan untuk memenuhi dengan hukum Islam dan operasi di bawah } \\
\text { prinsip- prinsip Undang- Undang Zakat } \\
\text { Mencakup pengetahuan, kemampuan, kesopanan dan sifat dapat dipercaya } \\
\text { yang dimiliki bank syariah, bebas dari bahaya, risiko atau keragu-raguan } \\
\text { Keinginan bank syariah untuk membantu Muzzaki dan memberikan pelayanan } \\
\text { dengan tanggap } \\
\text { Bank syariah menyediakan fasilitas fisik, perlengkapan, pegawai dan sarana } \\
\text { komunikasi } \\
\text { Bank syariah memberikan kemudahan dalam melakukan hubungan, komunikasi } \\
\text { yang baik, perhatian pribadi dan memahami kebutuhan para Muzzaki } \\
\text { Kemampuan memberikan pelayanan yang dijanjikan dengan segera, akurat dan } \\
\text { memuaskan }\end{array}$ \\
\hline 2 & $\begin{array}{l}\text { Kepuasan } \\
\text { Muzzaki }\end{array}$ & $\begin{array}{l}\text { Kepuasan semua Muzzaki } \\
\text { Pemenuhan ekspektasi pelanggan } \\
\text { Komparasi dengan pelayanan yang ideal }\end{array}$ \\
\hline 3 & $\begin{array}{l}\text { Loyalitas } \\
\text { Muzzaki }\end{array}$ & $\begin{array}{l}\text { Niat Muzzaki untuk berzakat kembali } \\
\text { Muzzaki mau merekomendasikan kepada yang lain } \\
\text { Bank syariah memberikan toleransi pelayanan } \\
\text { Bank syariah menjadikan muzaki nasabah utama }\end{array}$ \\
\hline
\end{tabular}

Sumber: Huda 2015, dan data olahan sekunder, 2019

Indikator Kinerja Islamic Social Responsibility (ISR) dalam penelitian ini:

Tabel 6. Indikator Kinerja Islamic Social Responsibility (ISR)

\begin{tabular}{|c|c|c|}
\hline No & Kriteria & Pelaksanaan \\
\hline \multirow[t]{5}{*}{1} & Kepatuhan & Instrumen- Instrumen Bank Syariah sesuai dengan syariah \\
\hline & Syariah & Pembiayaan Bank syariah sesuai dengan ketentuan syariah \\
\hline & & Investasi pada tempat dan produk yang $\mathrm{h}$ alal \\
\hline & & Menghindari keuntungan yang di dapat secara tidak halal \\
\hline & & Pemilihan stakeholder dengan kehendak syariah \\
\hline \multirow[t]{4}{*}{2} & Keadilan dan & Adanya nilai- nilai persaudaraan \\
\hline & Kesetaraan & Pelayanan yang berkualitas \\
\hline & & Tidak adanya diskriminasi \\
\hline & & Mempunyai kesempatan yang sama \\
\hline \multirow[t]{8}{*}{3} & Bertanggung & Amanah \\
\hline & Jawab dalam & Bekerja sesuai dengan kewajiban dan tanggung jawab \\
\hline & Bekeria & Memenuhi tuntutan akad \\
\hline & & Ikhlas \\
\hline & & Optimal dalam penggunaan waktu dan kepakaran \\
\hline & & Mengurangi image buruk dalam investasi \\
\hline & & Integritas dalam bekerja \\
\hline & & Berlaku adil dalam persaingan \\
\hline
\end{tabular}


Tempat bekerja yang aman dan nyaman

Kesejahteraan

Kebebasan berkehendak

Upah yang sesuai

Pelatihan dan pendidikan

Jam kerja yang manusiawi

Pembagian keuntungan dan kerugian yang adil

5 Jaminan

Memastikan realisasi program bank syariah tidak merusak alam sekitar

Kelestarian Alam

Ikut berperan aktif dalam menjaga alam sekitar

Mendidik pekerja untuk menjaga dan merawat alam sekitar

Menggunakan bahan-bahan ramah lingkungan dalam memenuhi

keperluan Bank syariah

6 Bantuan

Pemilihan lembaga yang dapat menunjang visi bank syariah dan

Kebajikan mlemenuhi misi Islamic Social Responsibility

lkut meringankan masalah sosial

Membantu program sosial kemasyarakatan

Menjalankan program Islamic Social Responsibility dengan tidak hanya berorientasi pada keuntungan semata-mata

Pemberdayaan masyarakat melalui produk-produk bank syariah

Sumber: Yusuf, Yasir: 2017

Indikator Variabel penelitian terikat $Y_{1}$ dan $Y_{2}$ sebagai berikut:

Tabel 7. Indikator Variabel Penelitian $\left(Y_{1}\right)$ Pengelolaan Zakat

\begin{tabular}{clc}
\hline No & \multicolumn{1}{c}{ Konstruk } & Indikator Variabel \\
$\mathbf{1}$ & Service Quality & Likert \\
$\mathbf{2}$ & Kepuasan Pelanggan/Muzzaki & Likert \\
$\mathbf{3}$ & Loyalitas Pelanggan/Muzakki & Likert \\
\hline
\end{tabular}

Sumber: data olahan sekunder, tahun 2019

Tabel 8. Indikator Variabel Penelitian ( $\left.\mathrm{Y}_{2}\right)$ Islamic Social Responsibility (ISR)

\begin{tabular}{clc}
\hline No & \multicolumn{1}{c}{ Aspek Kinerja ISR } & Indikator Variabel \\
1 & Kepatuhan Syariah & Likert \\
2 & Keadilan dan Kesetaraan & Likert \\
3 & Bertanggung Jawab dalam Bekerja & Likert \\
4 & Jaminan Kelestarian Alam & Likert \\
5 & Bantuan Kebajikan & Likert \\
\hline
\end{tabular}

Sumber: data olahan sekunder, tahun 2019

\section{Uji Persamaan Regresi Linear Berganda}

Uji regresi digunakan untuk meramalkan suatu variabel (variabel dependent) berdasarkan satu variabel atau beberapa variabel lain (variabel independent) dalam suatu persamaan linear. $\mathrm{Y}=\mathrm{a}+\mathrm{b}_{1} \mathrm{X}_{1}+\mathrm{b}_{2} \mathrm{X}_{2} \ldots+\mathrm{bn} \mathrm{Xn}$ persamaan linear dengan beberapa variabel independent. (Trihendradi, C. 2013).

$$
Y_{1}=a+b_{1} X_{1}+b_{2} X_{2}+\varepsilon
$$




$$
Y_{2}=a+b_{1} X_{1}+b_{2} X_{2}+\varepsilon
$$

Keterangan :

$\mathrm{Y}_{1}=$ Pengelolaan Zakat

$\mathrm{Y}_{2}=$ Islamic Social Responsibility (ISR)

$\mathrm{X}_{1}=$ Komisaris

$\mathrm{X}_{2} \quad=$ Direksi

$\mathrm{a}=$ Konstanta

$\mathrm{b} \quad=$ Koefisien

$\varepsilon=$ error

\section{Hasil Penelitian dan Pembahasan}

Hasil Uji Heteroskedastisitas

Scatterplot

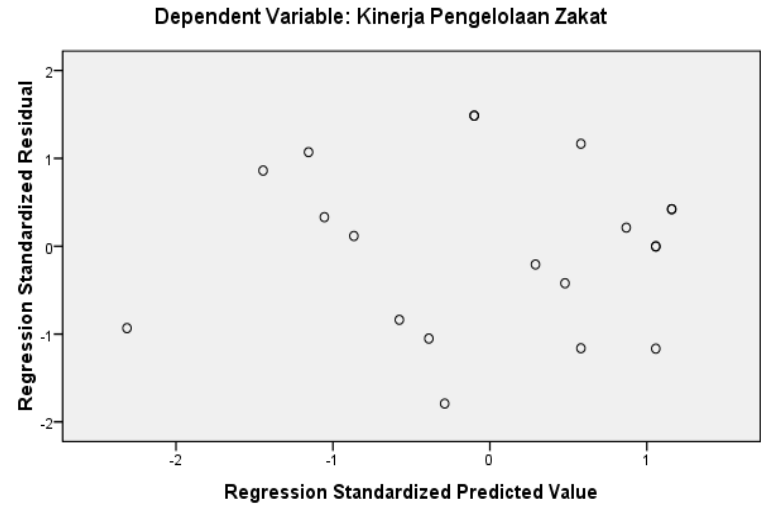

Gambar 2

Scatterplot

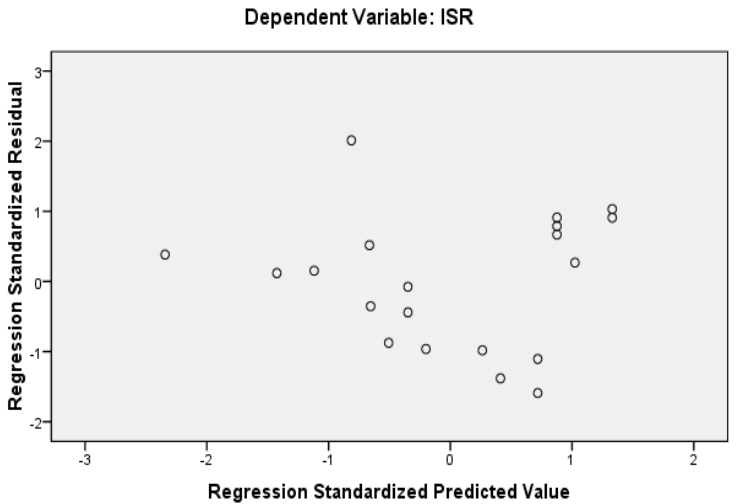

Gambar 3 
Pada Scatter Plot dapat dilihat bahwa nilai residual tersebar merata dan tidak membentuk pola tertentu sehingga dapat disimpulkan bahwa variabel independen $\mathrm{X}_{1}$ dan $\mathrm{X}_{2}$ dalam penelitian ini tidak mengalami gejala heterokedasitas.

\section{Peranan Komisaris $\left(X_{1}\right)$ dan Direksi $\left(X_{2}\right)$ dalam Pengelolaan Zakat $\left(Y_{1}\right)$}

Tabel 9

Coefficients ${ }^{a}$

\begin{tabular}{|l|r|r|r|r|r|}
\hline & \multicolumn{2}{|c|}{ Unstandardized Coefficients } & \multicolumn{1}{c|}{$\begin{array}{c}\text { Standardized } \\
\text { Coefficients }\end{array}$} & & \\
\cline { 2 - 4 } & $\mathrm{B}$ & Std. Error & Beta & $\mathrm{t}$ & \multicolumn{1}{c|}{ Sig. } \\
\hline 1 Model & 5.046 & 1.575 & & 3.204 & .005 \\
Peranan Komisaris & 1.184 & .360 & .660 & 3.291 & .004 \\
Peranan Direksi & .636 & .382 & .334 & 1.667 & .114 \\
\hline
\end{tabular}

a. Dependent Variable: Kinerja Pengelolaan Zakat

$$
Y_{1}=5.046+1.184 X_{1}+0.636 X_{2}+\varepsilon
$$

a) Peranan Komisaris berpengaruh signifikan terhadap pengelolaan zakat.

b) Peranan Direksi berpengaruh signifikan terhadap pengelolaan zakat

Menurut PSAK 109 tentang akuntansi zakat dan infak/ sedekah efektifitas dan efisiensi pengelolaan zakat bergantung pada profesionalisme amil karena zakat dan infak/sedekah yang diterima oleh amil harus dikelola sesuai dengan prinsip syariah dan tata kelola yang baik. (SAK Syariah, 2019: 109.3)

\section{Peranan Komisaris $\left(\mathrm{X}_{1}\right)$ dan Direksi $\left(\mathrm{X}_{2}\right)$ dalam ISR $\left(\mathrm{Y}_{2}\right)$}

Tabel 10

Coefficients $^{a}$

\begin{tabular}{|l|r|r|r|r|r|}
\hline \multirow{2}{*}{ Model } & \multicolumn{2}{|c|}{ Unstandardized Coefficients } & \multicolumn{1}{|c|}{$\begin{array}{c}\text { Standardized } \\
\text { Coefficients }\end{array}$} & & \\
\cline { 2 - 4 } & $\mathrm{B}$ & Std. Error & Beta & \multicolumn{1}{c|}{$\mathrm{T}$} & \multicolumn{1}{c|}{ Sig. } \\
\hline 1 (Constant) & 13.856 & 15.062 & & .920 & .370 \\
$\begin{array}{l}\text { Peranan } \\
\text { Komisaris }\end{array}$ & -2.285 & 3.440 & -.468 & -.664 & .516 \\
Peranan Direksi & 7.007 & 3.651 & 1.352 & 1.919 & .072 \\
\hline
\end{tabular}

a. Dependent Variable: ISR

$$
Y_{2}=13.846-2.285 X_{1}+7.007 X_{2}+\varepsilon
$$

a) Peranan Komisaris tidak berpengaruh signifikan terhadap pelaksanaan ISR.

b) Peranan Direksi berpengaruh signifikan terhadap pelaksanaan ISR. 
Hasil penelitian ini menunjukkan secara parsial peranan komisaris bank syariah dalam pengelolaan zakat, sedangkan peranan direksi bank syariah berpengaruh dalam pengelolaan zakat dan pelaksanaan ISR. dari rujukan penelitian yang dilakukan Dahlan 2018 membuktikan saat nasabah sudah mencapai tingkat mandiri maka nasabah sudah tidak memiliki hak untuk menerima zakat sehingga nasabah akan bermitra dengan bank syariah. Diperlukan ketelitian dan kecermatan para amil zakat. (Hasan,2015:92)

\section{Kesimpulan}

Bank syariah dapat bermitra dengan Muzzaki saat Muzzaki memiliki kepercayaan kepada bank syariah, mereka yakin bahwa kepatuhan syariah, keadilan dan kesetaraan antar nasabah, profesionalisme yang ditunjukkan bank syariah mampu merubah image buruk bank syariah yang tidak mengharapkan keuntungan semata.

\section{Saran}

Bank syariah harus terus menjaga hubungan baik dengan Muzzaki dan nasabah lainnya serta masyarakat luas.

\section{Ucapan Terima Kasih}

Terima Kasih tim peneliti ucapkan kepada Yayasan Pendidikan Nasional Tridinanti (YPNT) No. 133/UTP.A12/LPPM/V/2019 yang telah memberikan dukungan moril dan Kemenristekdikti atas bantuan dana Penelitian PDP Tahun Anggaran 2019 No.108/SP2H/LT/DRPM/2019, Tgl 11 Maret 2019.

\section{Referensi}

Badan Amil Zakat Nasional. Statistik Zakat Nasional Tahun 2017. Diakses pada https://pid.baznas.go.id/wp-content/uploads/2019/02/STATISTIK-ZAKATNASIONAL-2017.pdf.

Cetak Biru Pengembangan Ekonomi Syariah. Diakses tgl 20 April 2019 pada https://www.bi.go.id/id/ekonomidankeuangansyariah/CetakBiru/Contents/default.asp $\underline{x}$.

Dahlan, Dahnila. Bank Zakat: Pengelolaan Zakat dengan Konsep Bank Sosial Berdasarkan Prinsip Syariah. Jurnal Ekonomi dan Bisnis Islam. Volume 4 Nomor 2, JuliDesember 2018. Halaman 156-165.

Dakhoir, Ahmad. (2015). Hukum Zakat. Penerbit Aswaja Pressindo. Surabaya.

Gubernur BI: Indonesia Punya Potensi Zakat 210 Triliun. 24 Januari 2018, diakses pada tgl 19 April 2019 pada https://tirto.id/gubernur-bi-indonesia-punya-potensizakat-rp210-triliun-cDLd

Hasan, M Ali. (2015). Zakat dan Infak: Salah Satu Solusi Mengatasi Problema Sosial di Indonesia. Edisi 1 Cet 3. Prenadamedia Group. Jakarta. 
Hasan, Iqbal. (2008). Pokok- Pokok Materi Statistik 2 (Statistik Inferensif). Bumi Aksara. Jakarta.

Hery. (2018). Akuntansi Syariah. PT Gramedia Widiasarana Indonesia. Jakarta.

Huda, Nurul dkk. (2015). Zakat Perspektif Mikro-Makro Pendekatan Riset. Edisi 1 Cet 1. Prenadamedia Group. Jakarta.

Kemenag: Potensi Zakat Nasional Capai 217 Triliun, dari artikel Khasanah tgl 23 Februari 2018. Diakses pada https://www.republika.co.id/berita/duniaislam/islamnusantara/18/02/23/p4m1gs409-kemenag-potensi-zakat-nasionalcapai-rp-217-triliun.

Mujahidin, Akhmad. (2017). Ekonomi Islam: Sejarah Konsep, Instrumen, Negara dan Pasar. Ed Revisi Cet 4. PT Raja Grafindo Persada. Depok.

Nurhayati, Sri dan Wasilah. (2016). Akuntansi Syariah di Indonesia. Edisi 4 Cet 2. Penerbit Salemba Empat. Jakarta.

Putra, Dedi Kurnia Syah. (2019). Komunikasi CSR Politik Membangun Reputasi, Etika, dan Estetika PR Politik. Edisi 1 Cet 2. Prenadamedia Group. Jakarta.

Trihendradi, C. (2013). Langkah Mudah Menguasai SPSS 21. Penerbit Andi. Yogyakarta.

SAK (Standar Akuntansi Keuangan) Syariah Per Januari (2019). Cetakan Pertama: Januari 2019. Ikatan Akuntan Indonesia. Jakarta.

Surat Edaran Nomor 10/SEOJK.03/2014. Lampiran 2. Tentang Penilaian Tingkat Keseh atan Bank Umum Syariah dan Unit Usaha Syariah. OJK.

Wibisono, Yusuf. (2016). Mengelola Zakat Indonesia. Penerbit Kencana. Jakarta.

Yusuf, M Yasir. (2017). Islamic Corporate Social Responsibility (I-CSR) pada Lembaga Keuangan Syariah (LKS) Teori dan Praktik. Kencana Prenadamedia Group:Depok. 